\title{
Justice on Turtle Island: Continuing the evolution of policing with First Nations, Métis and Inuit Peoples in Canada
}

\author{
Robert (Bob) Chrismas*
}

\begin{abstract}
The relationship between policing and Canada's First Nations and Métis peoples has historically been strained, and these tensions continue trans-generationally. This social innovation paper explores the possibility of integrating two effective paradigms that might positively enhance the relationship between policing and First Nations, Métis and Inuit peoples of Canada. The first is increased multi-sectoral collaboration around social issues, based on proven models such as Prince Albert Saskatchewan's community mobilization initiative. The second is finding culturally sensitive alternatives to criminal courts by diverting cases into restorative justice processes that resonate more closely with Indigenous beliefs. These approaches would focus more on restoring community balance than pitting adversaries against one another in the mainstream criminal courts. Proposed for consideration is widening the restorative justice circle to include multi-sectoral resources to reduce the chances of re-offending and enhance conflict intervention and resolution.
\end{abstract}

Key Words Restorative justice, police legitimacy, community policing, First Nations

Journal of CSWB. 2016 Aug;1(2):44-50

www.journalcswb.ca

\section{INTRODUCTION}

Turtle Island is North America in the traditional teachings of First Nations peoples (Newcombe, 2011). It is considered the home of the various First Nations tribes, and the predecessor of European settlers who later colonized the United States and Canada. There is a growing public awareness and discourse around the continuing impacts of Canada's colonization on its Indigenous, First nations, Métis and Inuit peoples (hereafter referred to as Indigenous). We now have broad acknowledgement of the need to address the disparity and social injustices that have resulted from colonial programs that sought to integrate Indigenous peoples with European settler society. These programs included Canada's residential schools and 1960's mass forced adoption of Indigenous children into white families. It is a current issue; the last residential school did not close until 1996 (CBC, 2008), and Canada's Truth and Reconciliation Commission (TRC) final report was released this year (TRC, 2016). The TRC report has gone a long way towards acknowledging and raising awareness of the far-reaching impacts of settlement on Canada's Indigenous peoples. Canada's impending Missing and Murdered Aboriginal Women Inquiry, one of the first orders of business for the new Liberal government, may take our national understanding of Canada's First Nations Peoples to a deeper level.

Some have argued that the impetus to correct past injustices is increased by the need to reduce the disproportional demand that Indigenous peoples have had, as a result of injustices beyond their control, on Canada's medical, child welfare, social welfare, and justice systems (Donohue, 2007). First Nations populations are so prominent in Canada's prisons that some are calling them the "new residential schools" (Macdonald, 2016). In my own book that was based largely on my 30 years of experience working in Manitoba's justice system, I referred to Canada's jails as the new reserves (Chrismas, 2013). First Nations people comprise over 70 per cent of Manitoba jail populations, increased from 10 per cent in the 1950s (Hallet et al., 2006). This seems endemic across Canada, but it is not a phenomenon that is unique to this country. Sheldon (2001) described the American justice system as targeting people in lower socio-economic strata, perpetuating existing hierarchies of class, gender, and race. Some might argue that the same is occurring in Canada.

Some estimate that over ten per cent of Canada's approximately 25,000 federal prison inmates, many of whom are Indigenous, suffer from Fetal Alcohol Spectrum Disorder (FASD), a brain injury caused by maternal consumption of 
alcohol during pregnancy (Sanders \& Welch, 2011). The European introduction of alcohol, initially in trade for assistance in trapping for beaver pelts, can be attributed, at least in part, to the start of the legacy of substance abuse that is now inherent in many of Canada's Indigenous communities. The links between alcohol abuse and crime, victimization and diminishing community order and safety are well documented and understood (McFee \& Taylor, 2014; CMPA, 2013). How do we best address antecedents of crime, such as alcohol abuse? Does our justice and prison system address root causes, such as the trans-generational impacts of colonization that we now understand our Indigenous peoples are living with?

Volkan (1997) has highlighted how trauma tends to carry forward from generation to generation; this explains a lot about the social problems that we are seeing in contemporary Indigenous youth. Imprisoning people as a result of behaviour problems that are deeply rooted, systemic, and passed on between generations, rather than effectively eliminating the root causes, it could be argued, amounts to structural violence against them. The financial impacts alone may compel mainstream government and society to improve engagement of Indigenous peoples in correcting for past injustices and forging a more cohesive and healthy collective future for all Canadians.

Distrust of the police, the justice system and government in general may be endemic in many populations, in particular within Indigenous communities that are vastly over-represented in Canadian prisons and the justice system (Chrismas, 2012, 2013). During the course of my over 30 years working in Manitoba's justice system, many Indigenous people have told me that their experiences with the police have mainly involved seeing their relatives and friends being arrested. So it seems there's room for much research into how this trust could be rebuilt in future generations. Sir Robert Peel, credited with establishing the principles of good policing, highlighted that communities grant police legitimacy (Lentz \& Chaires, 2007). It could be argued that the future relationship of police agencies with Indigenous and other minority populations will depend upon successful trust-building and engagement. The relationship could hinge on people seeing the police as legitimately representing their interests, not just those of others.

Community safety and crime prevention does not stop with the police. It is now widely recognized in Canada that the police are only one element in the broad spectrum of stakeholders around crime prevention, and that multi-sectoral approaches are likely most effective (Russell \& Taylor, 2014; Chrismas, 2012). This social innovation paper will briefly explore the colonial history that has led us to the current situation, the police-Indigenous relationship in Canada, and possible paths forward. In particular this paper will briefly explore multi-sectoral and restorative approaches to social problems and how these two effective paradigms may be integrated for greater overall success.

\section{COLONIAL IMPACTS AND POLICING}

Indigenous Canadians were integral to early European trade networks that exploited exportable Canadian natural resources; they were also politically, economically, and socially marginalized during the settlement that accompanied these and later industries. The significance of land for Indigenous people is now better understood as scholars have found that their oral traditions are story-based and linked inextricably to landmarks and geographic areas (Lederach, 2005). Therefore, physical landmarks become a significant part of the Indigenous identity. Canadian conflicts, such as the protracted siege by the Mohawk tribe near the Quebec town of Oka in summer 1990 (Simpson \& Ladner, 2010), have largely defined the police community relationship in many regions. Ladner, a recognized expert on Indigenous Canadian history has noted that, if the economic disparity between mainstream Canada and the Aboriginal communities is not resolved through settlement of the seven treaties in the next 20 years, "It will not be pretty, Oka was nothing". The list of land related conflicts between Indigenous and mainstream Canada goes on, but two particularly poignant classics that have been written on the subject are Campbell's Halfbreed: A proud and bitter Canadian legacy (1974) and Night Spirits: The story of the relocation of the Sayisi Dene by Bussidor and Bilgen-Reinart (1997).

In 2012, First Nations leaders from across Canada met in Ottawa to form a national plan to fight for their rights. Former Assembly of First Nations Grand Chief Ovide Mercredi stated, "The option for us is very clear, we have to make our own laws and ignore Parliament." Mercredi said there is little the country can do if First Nations peoples unite, stating, "Parliament can pass all the laws they want, we'll just ignore them. They'll try to enforce them, but who's going to do that? The RCMP?" It seems that unresolved Treaty claims and land disputes will only worsen if they are not resolved (Paul, 2012). The police are often caught in the middle, mandated to enforce the laws while simultaneously striving to build trust and promote peace and community balance. Oka was a clear example of this, and there have been many others. Over recent years, this effect of land disputes on policing relationships has been a topic of interest at the Canadian Association of Chiefs of Police Policing with First Nations Métis and Inuit Peoples Committee, on which I serve as a member. Corporations such as the railways are, in many cases, quickly seeking court injunctions ordering the police to remove protestors from contested lands. Large amounts of revenue are at stake. In some cases the police are reluctant to enforce orders where they know it might inflame a situation or damage relationships.

While the English and French fought for control of Canadian trade routes, Canadian Indigenous peoples suffered the introduction of European illnesses, alcohol, and the politics of European contact. This is why many scholars speak in terms of pre and post contact. Canada's first laws authorized control by the Hudson Bay Company over beaver pelt exportation to Europe (Duhaime, 2008). Indigenous Canadians, who prior to first European contact had lived traditionally as hunters and gatherers, were marginalized while Canada's natural resources were exported back to Europe.

Some have argued that Canada's 'Indian Act' of 1876 intended to integrate First Nations peoples into European settler culture (Younging, 2009). Certainly, some of the more aggressive assimilation policies implemented through mandatory, church-run and government-funded residential schools were designed to rid First Nation peoples of their languages and cultures and integrate them into European 
settler society (Galley, 2009). We now have a deeper understanding of the importance of land to Indigenous peoples' worldviews, and how displacing them onto reserves has often disconnected them from nature and permanently damaged their sense of identity. Living conditions on the reserves has continually deteriorated. Canada's Department of Indian and Northern Affairs reported in 2006 that 50 per cent of people on reserves were on social assistance, and 90 per cent were unemployed (Indian and Northern Affairs Canada, 2006). Many of Canada's reserves still do not have adequate electricity or safe drinking water (Levasseur \& Marcoux, 2015). Many of these challenges can be linked back to the land and the effects of displacement. Beatty says, "Often what is being contested and protested [by Indigenous people] is the neglect of culturally appropriate resource considerations, incongruent conceptions of terms such as land rights and tenure, and overall skepticism of the capitalistic underpinnings of modern society" (2015, p.16). In 2008, the national government formally apologized for the failed residential schools (Menzies, 2009). The 'apology' acknowledged unsettled treaty rights to redistribution of wealth (Chrisjohn \& Wasacase, 2009). Canada and its government institutions, such as the police, may have a long way to go to overcome its past.

The Royal Canadian Mounted Police (RCMP) were agents in Canada's settlement and were often required to act as truant officers for the residential schools (LeBeuf, 2011). The resulting community distrust of the police is a lasting legacy. In his report on the RCMP's part in the residential school system, LeBeuf wrote that there is no mention of the RCMP role in the residential schools in existing literature or history books; however, the memory and perception among Indigenous peoples links the RCMP with assisting Indian Agents enforcing the Indian Act and the Family Allowance Act, enforcing the pass system that controlled movements on and off of the reserves, and government bans that prohibited Indigenous people from consuming liquor or holding dances and ceremonial gatherings. In 2004, the RCMP Commissioner officially apologized for its involvement in the "Indian Residential School Legacy" (RCMP, 2004).

Of course, this is early history and police in every province have since had their own tensions with Indigenous communities. Some examples include the 1995 protest at Ipperwash Provincial Park in Ontario, when Dudley George was killed by a police officer (Linden, 2007), the aforementioned 1990 Oka crisis in Quebec, the protracted and intractable land dispute in Caledonia, Ontario since 2006 (DeVries, 2011), the 1990 conviction of police officers in Saskatoon for conducting starlight tours that resulted in several deaths (Brass, 2004), ... and the list goes on across Canada.

The resulting inquiries over all of these events have produced many similar recommendations. For instance, Manitoba's Aboriginal Justice Inquiry that followed the shooting of J.J. Harper by a Winnipeg Police officer in 1988, recommended increased consultation with Aboriginal communities in the areas of education, justice, law enforcement, the courts, and prison system and increased recruitment of Indigenous people in policing (Hamilton \& Sinclair, 1999). Despite numerous development and recruitment programs in Manitoba and across Canada, Indigenous people are still generally under-represented in policing (Li, 2008; Police Sector Council, 2007).
Establishing, rebuilding, and maintaining trusting relationships with First Nations peoples is an ongoing concern for Canada's law enforcement agencies. The principles of good policing that were originally set out by Sir Robert Peel when establishing London's first Metropolitan Police Force in 1829, are a doctrine for professional policing in the Western World that remains apposite to this day (Lentz \& Chaires, 2007). These principles, if properly applied, can stand as a guide for police transformation and improved respect for traditional Indigenous cultures. Principle number seven, commonly stated as "The police are the people and the people are the police', highlights the role of the community in public safety. Peel's principals define the police as an extension of the public, not as a replacement of them. The idea that the police are one of many stakeholders and not solely responsible for crime reduction and public safety, is an underpinning principle in the collaborative approaches to policing being undertaken across Canada.

\section{NEW POLICING MODELS ARE EMERGING}

Ever increasing police budgets are a growing concern in most, if not all, Canadian cities and jurisdictions. While overall crime has reportedly dropped over recent decades, the demands on policing continue to rise (Chrismas, 2013). As a result, the recent discourse on the economics of policing emphasizes efficiency and getting more from existing resources, not necessarily increasing them. One way that might occur is through improved community partnerships and shared responsibility.

Many police agencies are coming to realize that continuing effectiveness depends upon vigilance to public support and legitimization, and enhanced partnerships. Taylor-Butts (2002, p. 72), wrote, "It is not enough to focus on actual quality of police performance, since police agencies may execute their job duties effectively and constitutionally and still find themselves without community support." For decades now, Canadian police agencies have strived to engage citizens and be seen as responsive to changing community needs through various reiterations of community oriented policing. Greene (1987) described how community oriented policing developed as a formal concept in the 1950s and '60s in Canada, seeking to improve interaction between police and the communities they serve. Cooke-Scott (1998, p. 120) wrote, "Community policing represents a fundamental shift in police services management and has replaced the military model as the dominant service delivery model in Western Countries."

The Halton Regional Police Service (HRPS), in Ontario Canada, was one of the earliest comprehensive community policing programs implemented in North America (CookeScott, 1998). Halton's experience revealed that implementation and change to community-oriented policing approaches can be challenging. Substantial change requires commitment and momentum (Cooke-Scott, 1998). Willis (2011, p. 654) wrote that community policing has been defined in different ways. It is a philosophy designed to reduce crime through community partnerships, problem solving, and the decentralization of decision-making authority to front-line officers (Scheider, et al., 2009). Community-oriented policing has been pursued due to the mass of evidence that conventional reactive practices in overall crime suppression are generally less effective 
than approaches that seek to address the root causes of crime, rather than just reacting to them. While community-oriented policing is widely endorsed by those involved in it, Bayley (1988) has pointed out that the term actually means different things to different people. For example, different police departments have placed emphasis on different aspects, including: crime prevention seminars, satellite communitybased storefronts, newly designed uniformed patrol beats and foot patrols, community advisory groups and forums, neighbourhood watch programs, and programs designed to make the police more visible in neighbourhoods. The most recent trends in community-oriented policing have engaged the various sectors and service agencies in regular information sharing and meetings in a highly successful model originating in Prince Albert Saskatchewan (McFee \& Taylor, 2014). Prince Albert Police Chief Dale McFee recognized that high crime rates tied to antecedents, such alcohol abuse, were on an unsustainable trajectory and called for a new approach to intervention (McFee, 2010). He sent a delegation to Glasgow Scotland to learn from a successful community mobilization approach that had brought various service sectors together for effective crime reduction (Govanhill, 2010). The Prince Albert Hub model brought various sectors together around "risks" that were identified in the community, in many cases intervening before issues became policing related problems (McFee \& Taylor, 2014). This model of community mobilization around social issues boasted a 37 percent reduction in violent crime between 2010 and 2014 in Prince Albert. However, the architects of the Prince Albert Model also highlight that different regional dynamics might significantly affect the effectiveness of this program in different places (McFee \& Taylor, 2014). The model set out by Prince Albert is now being emulated in various forms in well over 50 communities across Canada. The main lesson we have learned from the Saskatchewan initiative is that the police are only one element in the spectrum of government services, including health, child and social welfare and education, sectors that are also significant to crime prevention, and more broadly, community safety and well-being, along with police, courts, and prisons.

\section{NEW SKILLS AND NEW CULTURES REQUIRED}

Improved communication and engagement foster trust between police agencies and the communities that they serve. Lederach (1995) emphasized the need for citizen empowerment to participate in solving society's problems. The narrative across society needs to evolve to engage whole communities working together to reduce crime and improve quality of life (Sandole, et al., 2009). However, increased citizen engagement and inclusion requires police willingness to accept input and share power. Nilson (2014, p. 13) points out that "Advocates of the Hub model are driven by the notion that the 'human service disconnect' in our contemporary bureaucracy makes it difficult for some individuals and families to get the supports they need." Manitoba's Block by Block, Community Safety and Well-being Initiative (Manitoba Government, 2016) was initially modelled after Prince Albert's HUB (multi-sector committee of front line service providers) and the COR (Centre of Responsibility), which is comprised of decision-makers from the involved government and non-government organizations (Nilson, 2014). As a serving member on the COR of the Thunderwing, which is the first initiative under Manitoba's Block by Block Initiative, I have observed Nilson's finding first hand. Many families come up against bureaucratic barriers that we can help with. It is a simple concept; however, bureaucratic challenges are often surprisingly difficult to rectify.

\section{MAKING CHANGE TAKES LEADERSHIP}

There are often challenges associated with implementing progressive policing models, and these are abundantly evident when it comes to interactions with Indigenous peoples. One of the first challenges is in defining the community. Flynn (1998) described the difficulties in defining what community means in reference to community-oriented policing. Sometimes the political divisions of a community do not fit with distinct cultural groups with different needs that exist in the same geographic or politically defined areas. There are 600 known First Nations communities in Canada, each with a different culture and background, and many with different languages. These areas may not fit within police jurisdictions or political boundaries (Flynn, 1998).

Resistance to change has also been documented as a significant barrier to innovation in policing historically, and I can speak from personal experience in the present. Lewis, et al. (1999) found that, among agencies that implemented community oriented policing approaches in the 1990s, resistance to change was a significant barrier. Police executives and chiefs can issue directives, but if they do not inspire officers to implement them, no long-term change will occur. Allen (2002) found that police officers working in agencies that affect major changes often revert quickly back to their former ways of doing things. Community policing is a process, and does not result automatically in overnight success (Cooke-Scott, 1998). Community-oriented approaches require the ability of executives and managers to inspire and empower officers. This also includes a willingness to shift responsibility, accountability and authority to individual officers in order to empower them in engaging the community. Progressive models may represent major paradigm shifts for many agencies that are entrenched in traditional hierarchical bureaucratic structures. Police agencies seeking to implement community-oriented approaches, or any major initiatives, need effective change management processes to ensure success. Regardless of these challenges, more community-oriented approaches that include Indigenous people as equal partners and stakeholders may hold the best chances of success in their engagement.

\section{RESTORATIVE JUSTICE}

Another barrier — and potential area of opportunity — with respect to engagement of Indigenous people may be the manner in which they are subjected to European justice models that are contrary to traditional Indigenous beliefs. Traditional restorative justice strategies may be more effective for Indigenous communities (Hamilton \& Sinclair, 1999). In traditional Indigenous belief systems, offenders and victims need to both be involved, along with the community, in restoring harmony after events that disrupt the peace (Canada Department of Justice, 2016; Linden, Clairmont \& Murphy, 2001). In many 
Indigenous communities of Canada, it may be important to have elders, political leaders, medicine men and women, in addition to the families of perpetrators and victims, involved in restorative mediation and justice processes.

The Community Justice Initiative of Waterloo Region (Ontario) is one example of a progressive and highly effective model of this. The director, Chris Cowie, reports extremely high success rates for cases in which both offenders and victims agree to participate in their restorative model (Personal communication, 4 February, 2016). In these cases, charges that have been brought before the court may be dropped if both parties agree to participate. Cowie reports that sometimes victims are reluctant to participate; in other cases, offenders are reluctant. However, reports Cowie, if and when they do both agree to restorative mediation, the outcome is almost always positive and more effective than that achieved in mainstream criminal courts. Another example of effective restorative justice integration with the mainstream justice system is the long-standing Community Justice Forum program that is run by the RCMP (2016). The RCMP restorative justice website sates, "The philosophy of restorative justice is based on community healing. In other words, the community decides what is best for itself in terms of resolving certain criminal matters." Bringing community justice forums together around conflicts, or incidents where one person has committed a crime against another can be a powerful conflict mediation tool. Having been trained as a community justice forum facilitator under this program in the mid-1990s, I found it to be extremely effective, but also logistically difficult for active police officers to manage.

The challenge will be in finding the resources to implement restorative justice models, which may require more work and resources up front, but in the long run are more effective in reducing continuing conflict. The RCMP initiated the program for community justice forums in 1996, based on a successful Australian model (Canada, Department of Justice, 2016). Training was offered across Canada and numerous police officers volunteered (myself included) and were trained as facilitators. The idea was to bring offenders and their supporters to a meeting with victims and their supporters in order to negotiate resolutions that work for all parties. In cases that met criteria agreed to by Crown attorneys, offenders could be diverted from the normal court system if they agreed to participate in a community justice forum. This process was extremely effective and offenders avoided criminal records (for minor first offences). Offenders often report feeling true remorse from meeting their victims face-to-face. Victims feel a sense of justice, something that often seems to be lost in the impersonal, formal, mainstream criminal court system.

One major challenge for community justice forums was logistics. The process takes significant coordination, time, and resources. For example, although I was trained, I never had the opportunity to conduct a forum because my position in uniform operations meant I lacked the time to gather all the required people together for a meeting.

Griffin described how restorative justice processes empower the community by involving many people (2001). Overall, the increased use of culturally sensitive restorative processes may offer the potential to reduce prison populations, expand accountability of offenders, and reduce reliance on policing and corrections processes through deeper community involvement. Again, the challenge is in finding the resources to implement restorative models in order to reduce long-term impacts and costs of criminalization and recidivism that we are currently experiencing (Taylor-Butts, 2000). In combination with promising practices in community engagement and mobilization as described above, restorative justice models, consensus, and self-government that respects Indigenous traditions, may combine well to empower the police, victims of crime, offenders, and communities as a whole, to improve social justice and quality of life.

\section{CONCLUSIONS}

The social innovation proposed here is to increase the use of restorative justice approaches and integrate them with multi-sectoral collaborative responses described in the first part of this article. A restorative justice approach could be taken to resolve conflict and restore balance after someone has been offended or victimized by another. But, as we've now seen with the Hub model and its variations, the circle could possibly be widened to include resources that can further address the root causes of a problem and reduce the chances of re-offending. This is an area for further research, and could be proposed as a pilot project for proof of concept.

The role of the police in such a blended model would be to defer charges in some cases, and to participate actively in the restorative circles. It would, however, not ideally be a policeled model. Ideally it would be a community-led initiative with active support and engagement from all sectors. Given our growing understanding of Indigenous cultures and values, and the current unsustainable trajectory of social problems in Indigenous communities, something must be done to intervene. Understanding that we are all co-inhabitants of Turtle Island, perhaps an innovation such as this is something well worth investigating.

\section{ACKNOWLEDGMENTS}

I wish to thank the expert peer reviewers and in particular, Editor in Chief Norm Taylor, and the journal editors for all of their constructive feedback and assistance in improving this article.

\section{CONFLICT OF INTEREST DISCLOSURES}

Robert (Bob) Chrismas is a serving staff sergeant in the Winnipeg Police Service. The author has no conflicts of interest connected to the submission of this article.

\section{AUTHOR AFFILIATIONS}

*The Winnipeg Police Service, Winnipeg, MB.

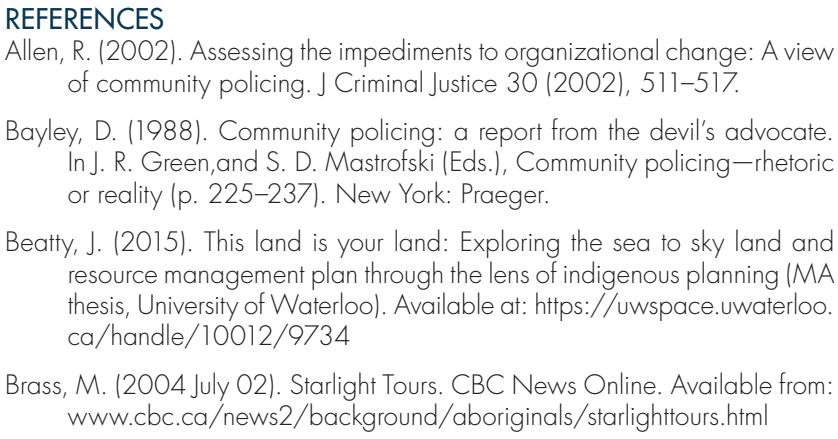

Beatty, J. (2015). This land is your land: Exploring the sea to sky land and resource management plan through the lens of indigenous planning (MA thesis, University of Waterloo). Available at: https://uwspace.uwaterloo. $\mathrm{ca} /$ handle/10012/9734

Brass, M. (2004 July 02). Starlight Tours. CBC News Online. Available from www.cbc.ca/news2/background/aboriginals/starlighttours.html 
Bussidor, I., and Bilgen-Reinart, U. (1997). Night Spirits: The story of the relocation of the Sayisi Dene. Winnipeg, MB: University of Manitoba Press.

Campbell, M. (1974). Halfbreed: A proud and bitter Canadian legacy. Toronto, ON: McClelland and Stewart Limited.

Canada, Department of Justice. (2016). Website on restorative justice. Available at: www.justice.gc.ca/eng/

CBC News. (2008 May 16). A timeline of residential schools, the Truth and Reconciliation Commission. Available at: www.cbc.ca/news/canada/ story/2008/05/16/f-timeline-residential-schools.html

Chrisjohn, R. \& Wasacase, T. (2009). Half-truths and whole lies: Rhetoric in the 'apology' and the Truth and Reconciliation Commission. In G. Younging, J. Dewar, and M. DeGagné (eds.), Response, Responsibility, and Renewal: Canada's Truth and Reconciliation Journey. Ottawa, ON: Aboriginal Healing Foundation.

Chrismas, R. (2013). Canadian policing in the 21 st century: A frontline officer on challenges and changes. Montreal, PQ: McGill-Queen's University Press.

Chrismas, R. (2012). The people are the police: Building trust with Aboriginal communities in contemporary Canadian society. Canadian Public Administration, 55(3), 451-470.

CMPA (2013). The case for a Prince Albert and Region alcohol strategy: A call to action for all community sectors to collectively develop and implement a comprehensive alcohol strategy. Prince Albert, SK: Community Mobilization Prince Albert. Available at: www.mobilizepa.ca/images/ documents/pdfs/2013CalltoActionTheCaseforAlcoholStrategy.pdf

Cooke-Scott, L.A. (1998). Community-based policing in Ontario: Lessons from the Halton Regional Police Service. Canadian Public Administration, $41(1), 120-146$

DeVries, Laura. (2011). Conflict in Caledonia: Aboriginal land rights and the rule of law. Victoria, BC: UBC Press.

Donohue, J. (2007). Economic models of crime and punishment. Soc Res, $74(2), 379-412$

Duhaime, L. (2008). Canada's criminal code: A history, In Duhaime's Encyclopedia of Law (online book). Available at: http://www.duhaime.org

Flynn, D. W. (1998). Defining the 'Community' in Community Policing. Police Executive Research Forum, US Department of Justice.

Galley, V. (2009). Reconciliation and the Revitalization of Indigenous Languages, In G. Younging, J. Dewar and M. DeGagné (editors), Response, responsibility, and renewal: Canada's truth and reconciliation journey. Ottawa, ON: Aboriginal Healing Foundation.

Govanhill, (2010). Three month review of the Govanhill Opertional Hub. Glasgow Centre for Population Health. Available at: www.gcph.co.uk/ work_themes/theme_2_urban_health/equally_well

Greene, J. R. (1987). Foot patrol and community policing: past practices and future prospects. American Journal of Police, 6, 1-15.

Griffin, I. (2001). The practical application of traditional Aboriginal healing practices as a restorative justice process: A case study of the Helen Betty Osborne story. M.S.W. dissertation. University of Manitoba, Winnipeg, Manitoba.

Hallett, B., Thornton, N., and Stewart, D. (2006). Aboriginal People in Manitoba. Winnipeg, MB: Aboriginal and Northern Affairs.

Hamilton, A. C. and Sinclair, M. (1999). Report of the Aboriginal Justice Inquiry of Manitoba. Vol. 1: The Justice System and Aboriginal People. Winnipeg, MB: Queen's Printer. Indian and Northern Affairs Canada (now Indigenous \& Northern Affairs Canada). https://www.canada. $\mathrm{ca} / \mathrm{en} /$ indigenous-northern-affairs. html

LeBeuf, M. (2011). The role of the Royal Canadian Mounted Police during the Indian residential school system. On behalf of the Royal Canadian Mounted Police (R C M P ). Available at: www.rcmp-grc.gc.ca/ aboriginal-autochtone/irs-spi-eng.htm

Lentz, S.A., and Chaires, R. (2007). The invention of Peel's principles: A study of policing 'textbook' history. J Criminal Justice, 35 (1), 69-79.

Lederach, J.P. (2005). The moral imagination: the art and soul of building peace. New York: Oxford University Press.
Lederach, J. (1995). Preparing for Peace: Conflict Transformation Across Cultures. New York, NY, USA: Syracuse University Press.

Levasseur, M. \& J. Marcoux. (2015). Bad water: 'Third World' conditions on First Nations in Canada: Two-thirds of First Nations have been under at least 1 water advisory between 2004 and 2014. CBC (14 October). Available from: www.cbc.ca/news/canada/manitoba/bad-water-thirdworld-conditions-on-first-nations-in-canada-1.3269500

Lewis, S., Rosenberg, H., \& Sigler, R.T. (1999). Acceptance of community policing among police officers and police administrators. Policing: An International Journal of Police Strategies and Management, 22(4), 567-588.

Li, Geoffrey. (2008). Private security and public policing. StatsCan catalogue no. 85-002-X. Juristat, 28(10). Available from: http://www.statcan. gc.ca/pub/85-002-x/2008010/article/10730-eng.htm

Linden, B. (2007). Report of the Ipperwash Inquiry. Toronto, ON: Office of the Attorney General. Available from: http://www.attorneygeneral.jus. gov.on.ca/inquiries/ipperwash/report/

Linden, R., Clairmont, D. \& Murphy, C. (2001). Aboriginal Policing in Manitoba: A Report to the Aboriginal Justice Implementation Commission. Winnipeg, MB: Aboriginal Justice Implementation Commission. Available from: www.ajic.mb.ca/policing.pdf

Macdonald, N. (2016 February 18). Canada's prisons are the 'new residential schools': A months-long investigation reveals that at every step, Canada's justice system is set against Indigenous people. Macleans. Retrieved from: http://www.macleans.ca/news/canada/canadas-prisons-arethe-new-residential-schools/

Manitoba Government. (2016). Block by Block Community Safety and Well Being Intitiative (website homepage). Winnipeg, MB: Government of Manitoba. http://www.blockbyblockinitiative.com

McFee, D.R. (2010). "Community mobilization: Business plan" (Draft 18) Prince Albert, SK. Prince Albert Police Service. p 9

McFee, D.R. \& Taylor, N.E. (2014). The Prince Albert Hub and the emergence of collaborative risk-driven community safety. Toronto, $\mathrm{ON}$ : Canadian Police College. Available from: http://www.cpc-ccp.gc.ca/sites/default/files/ $\mathrm{pdf} /$ prince-albert-hub-eng.pdf

Menzies, P. (2009). Homeless Aboriginal men: Effects of intergenerational trauma, In J.D. Hulchanski, P. Campsie, \& S.B. Chav, et al. (editors), Finding home: Policy options for addressing homelessness in Canada (Chapter 62). Toronto, ON: Cities Centre, University of Toronto. Available from: www.homelesshub.ca/Finding Home

Newcombe, S. (2011 September 30). Canada and the United States Are in Turtle Island. Indian Country Media Network. Retrieved from: http:// indiancountrytodaymedianetwork.com/2011/09/30/canada-andunited-states-are-turtle-island

Nilson, C. (2014). Risk-driven collaborative intervention: A preliminary impact assessment of Community Mobilization Prince Albert's Hub Model. Saskatoon, SK: Centre for Forensic Behavioural Science and Justice Studies, University of Saskatchewan.

Paul, A. (2012 November 30). Aboriginal leaders call for action on legislation. Winnipeg Free Press.

Police Sector Council. (2007). A national diagnostic on human resources in policing. Ottawa, ON: Police Sector Council, Government of Canada. Available from: http://www.policecouncil.ca/wp-content/ uploads/2013/03/National-Diagnostic-on-HR-in-Policing-2007.pdf

RCMP. (2004). RCMP apology. Available from: http://www.rcmp-grc.gc.ca/ aboriginal-autochtone/apo-reg-eng.htm

RCMP. (2016) The RCMP restorative justice website. Available at: http://www. rcmp-grc.gc.ca/pubs/ccaps-spcca/restjust-justrepar-eng.htm

Russell, H. \& Taylor, N.E. (2014). New directions in community safety: Consolidating lessons learned about risk and collaboration. Toronto, ON: Ontario Association of Chief's of Police. Available at : www.oacp.on.ca/ Userfiles/StandingCommittees/CommunityPolicing/ResourceDocs/ OWG\%20New\%20Directions\%20in\%20Community\%20Safety.pdf

Sanders, C., \& M. Welch. (2011). "When trouble is just one slip away." Winnipeg Free Press print, (9 March). Sandole, D., Byrne, S., Sandole- 
Staroste, I., \& Senehi, J. (2009). Handbook in conflict analysis and resolution. Oxford: Routledge.

Scheider, M.C., Chapman, R., \& Schapiro, A. (2009). Towards the unification of policing innovations under community policing. Policing: An International Journal of Police Strategies and Management, 32(4), 694-718.

Sheldon, R. (2001). Controlling the dangerous classes: A critical introduction to the history of criminal justice. Boston: Allyn and Bacon. Simpson, L., \& Ladner, K. (2010). This is an Honour Song: Twenty years since the blockades. Winnipeg, MB: Arbeiter Ring Press.

Taylor-Butts, Andrea. (2000). Justice Spending in Canada. Statistics Canada Catalogue no. 85-002-XIE. Juristat, 22(11). Available at: www.statcan. gc.ca/pub/85-002-x/85-002-×2002011-eng.pdf
TRC. (2016). Truth and Reconcilliation Commission of Canada (website) http://www.trc.ca/websites/trcinstitution/index.php? $p=3$

Volkan V. (1997). Bloodlines: From ethnic pride to ethnic terrorism. New York: Farrar, Strauss and Giroux.

Willis, J. (2011). Enhancing police legitimacy by integrating Compstat and community policing. Policing: An International Journal of Police Strategies \& Management,34(4), 654-673

Younging, G. (2009). Inherited history, international law, and the UN Declaration, In Gregory Younging, Jonathan Dewar, and Mike DeGagné (editors). Response, responsibility, and renewal: Canada's truth and reconciliation journey (p. 365-377). Ottawa, ON: Aboriginal Healing Foundation. 